\title{
Geo-electrical investigation of Leachate Impact on Groundwater: A Case Study of Ile- Epo Dumpsite, Lagos, Nigeria
}

\author{
ADEOTI, L; OLADELE, S; OGUNLANA, F O \\ Department of Geosciences, University of Lagos, Akoka, Lagos
}

\begin{abstract}
In the past few decades, disposal sites have been filled with household refuse and different kinds of potentially dangerous industrial waste in an uncontrolled manner which poses an enormous risk for the environment, and are the main sources for groundwater contamination. With the aim of assessing impact of leachate on the underlying aquifers by determining and delineating possible leachate infiltration into the aquifer matrix ,Constant Spacing Traversing (CST) was carried out using Wenner array and spacing between $10-60 \mathrm{~m}$ along four $160 \mathrm{~m}-180 \mathrm{~m}$ profiles. The results revealed the aquifer is characterized by low resistivity response generally below $4.5 \mathrm{ohm}-\mathrm{m}$ depicting possible contamination of the underlying aquifer from Oke-Odo landfill. The surface of the waste landfill is characterized by differential decomposition of waste as zones of advanced decomposition and fresh waste are reflected as low and high resistivity respectively. The absence of leachate in the aquifer $100 \mathrm{~m}$ from the studied area suggests that the leachate has not spread to this area, therefore, safe for groundwater exploitation. This study demonstrated the expeditiousness and effectiveness of the resistivity technique as a tool for geo-environmental mapping of leachate. @JASEM
\end{abstract}

Waste deposit represents one of the important and actual environmental problems. All through the recent past, unlined disposal sites have been filled with household refuse and different kinds of potentially dangerous industrial waste. This poses a huge risk for the environment, and is the main source for groundwater contamination. Once waste is deposited on a dumpsite, pollution can arise from degradation of waste and the migration of leachate. The management of solid waste landfills has been a major problem of Lagos and urban centres in Nigeria and other developing countries worldwide. Anthropogenic wastes are generated daily and disposed indiscriminately in rivers and landfills without recourse to the underground environment, local geology and their proximity to the living quarter (Ball and Stove, 2002). As a result of this, landfill is likely to remain a relevant source of groundwater contamination in foreseeable future (Ugwu and Nwosu, 2009). About 10 million gallons of water are extracted from the multi-layer aquifers of Lagos per day (Longe et al.1987). Therefore, buried waste at landfills threatens the health of the aquifer and the people, environment, and economy that depend on it.

This study presents a case study, where CSTs have been carried out for the detection and delineation of possible leachate infiltration into the aquifer matrix and to probe the geological setting of the study area from 2-D resistivity data, with a view to mapping out possible areas for groundwater development that will not be prone to pollution hazard. This study will improve our knowledge of subsurface features, properties, processes, and contaminant distributions, which in turn leads to better decision-making regarding site remediation and planning of future dumpsites.

\footnotetext{
*Email: lukuade@yahoo.com
}

Geologic Units within the Dahomey Basin: Stratigraphy of the eastern Dahomey basin has been discussed by various workers and several classification schemes have been proposed. These notably include those of Jones and Hockey (1964); Omatsola and Adegoke (1981); Billman (1992), Elueze and Nton (2004). The stratigraphy of Cretaceous to Tertiary sedimentary sequence of the eastern Dahomey basin can be divided into: Abeokuta Group, Imo Group, Ilaro Formation, Coaster plain sands and Recent alluvium. The Recent alluvium deposits, the continental Benin sands and the Ilaro Formations were identified as the major aquifers. The aquifers are essentially made of sands, gravels or a mixture of the two [Bureau de Recherches Geologiques et Minieres (1979)]. These aquifers are generally shallower than $200 \mathrm{~m}$ and can be classified into three types (Longe et al. 1987). The first is a water table aquifer that is prone to pollution because of its unconfined condition. The second and third aquifers are confined and made up of sequence of sand and clay.

\section{MATERIALS AND METHODS}

In this study, the field procedure involved geoelectrical investigations by Constant Spacing Traversing (CST) technique along four profiles AA' to DD' that were largely influenced by accessibility (Fig.1). Resistivity data were recorded using Wenner array along the profiles which varied from $160 \mathrm{~m}$ to $180 \mathrm{~m}$ in length and the data were acquired by means of four electrodes deployed along the profiles at an inter-electrode spacing ranging from $10 \mathrm{~m}$ to $60 \mathrm{~m}$. The geoelectrical data collected have been processed by means of Dipro modelling software in order to perform 2D geoelectrical data inversion. The inversion routines are based on the smoothnessconstrained least squares method (Sasaki, 1992; Loke and Barker, 1996). The quality of the inversion 
Geo-electrical investigation.....

output was guided by acceptable minimum absolute error (rms error) between the measured and predicted apparent resistivity. However, geophysical inversion inherently surfers from non-uniqueness, which can be reduced by constraining the inversion by the use of additional information. Consequently, one of the CST data was acquired in the vicinity of an existing borehole, $100 \mathrm{~m}$ from the dumpsite, in order to calibrate and correlate the resistivity responses with lithology, and observe the resistivity response of the aquifer at a distance from the dumpsite, thus serving as control. The electrical resistivity images of these four lines will be discussed and compared to resistivity values obtained from laboratory

\begin{tabular}{|l|c|}
\hline Sampled Material & Resistivity $(\boldsymbol{\Omega}-\mathbf{m})$ \\
\hline Leachate only & 2.994 \\
\hline Sand saturated with leachate & $4.97-5.04$ \\
\hline $\begin{array}{l}\text { Fresh waste (plant materials, rubber strands, and) } \\
\text { saturated with leachate }\end{array}$ & $6.03-7.16$ \\
\hline Soil saturated with leachate & $3.15-4.00$ \\
\hline Rain water only & 73.88 \\
\hline Sand saturated with rain water & $14.36-1750$ \\
\hline $\begin{array}{l}\text { Fresh waste (plant materials. rubber strands, and) } \\
\text { saturated with rain water }\end{array}$ & $19.71-22.50$ \\
\hline Soil saturated with rainwater & $9.30-10.57$ \\
\hline Clay saturated with brackish water & $0.12-0.20$ \\
\hline Clean sand saturated with sea water & $1.5-3.5$ \\
\hline Fresh sandstone & 600 \\
\hline Phyllite & 300 \\
\hline Hard rock & $>600$ \\
\hline
\end{tabular}
measurements for landfill an $\mathrm{d}$ other earth materials as shown in Table 1.

\section{RESULTS AND DISCUSSION}

Figure $2 \mathrm{a}$ shows the result of the resistivity model along traverse 1 (control), in the vicinity of an existing borehole, $100 \mathrm{~m}$ from the dumpsite. The model reveals homogenous high electrical resistive zone $(>740 \mathrm{Ohm}-\mathrm{m})$ at depth ranging from $5-30 \mathrm{~m}$ across the model. This observation reflects an unconfined aquifer saturated with fresh water (Table 1). From the high resistivity response of this zone, it is evident that this area is free from leachate contaminations and suitable for groundwater development. From the surface to about $5 \mathrm{~m}$ depth is a horizontal zone that thickens to the profile end having resistivity response ranging from $270-424$ $\mathrm{ohm}-\mathrm{m}$. This is interpreted as unpolluted top-soil. However, there is a local zone of low resistivity response at 100 to $130 \mathrm{~m}$ from the base point on the surface of this traverse. Table 1. Electrical Resistivity of Earth Materials (Shaharin, 1998)

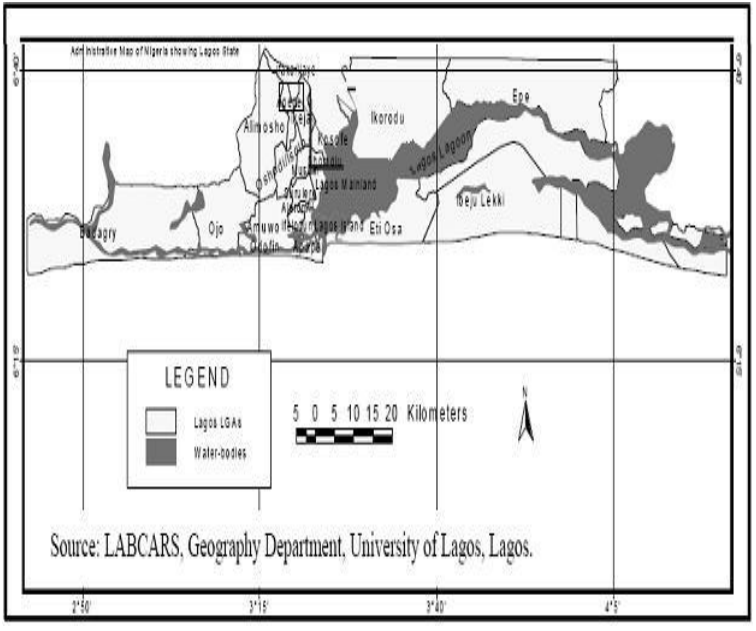

Fig.1: Location map of the survey area at Ilepo, Lagos 
Geo-electrical investigation.....
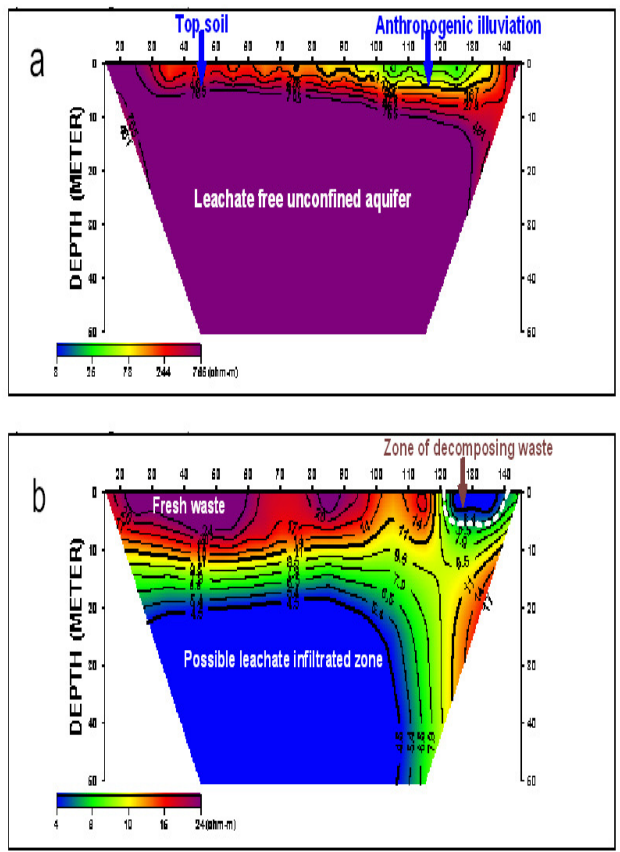

Fig.2: Inverted resistivity section along (a) traverse 1 and (b) traverse 2
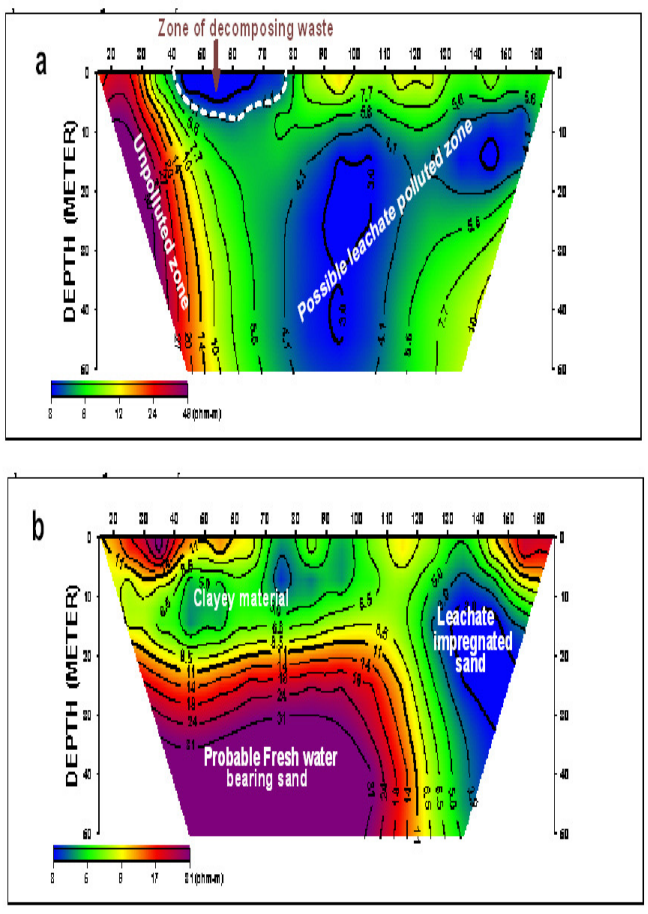

Fig.3: Inverted resistivity sections along (a) traverse 3 and (b) traverse 4

The 2-D Earth resistivity model obtained along traverse 2 is shown in Figure $2 \mathrm{~b}$. The inverse model ADEOTI, L; OLADELE, S; OGUNLANA, F O of this traverse shows a large conductive zone with uniform resistivity of less than $4.5 \mathrm{ohm}-\mathrm{m}$ at $20 \mathrm{~m}$ depth from the top of landfill. This zone, which occupies most of the area of the model section, is interpreted as possible polluted zone due to leachate infiltration from the landfill. The surface of the landfill shows variation in resistivity from high to low. At locations $20-60 \mathrm{~m}$ and $80-90 \mathrm{~m}$ from base point, there are local high resistivity zones (approx. $24 \mathrm{Ohm}-\mathrm{m}$ ) near the surface of the landfill, up to $5 \mathrm{~m}$ depth, indicating fresh waste saturated with rain water. At $180-200 \mathrm{~m}$ from the base point is a highly conductive zone $(<1 \mathrm{ohm}-\mathrm{m})$ signifying zone of highly decomposing waste saturated with highly conductive leachate. The link between this zone and the polluted zone underground suggests leachate infiltration from east to west. Thus, the surface of the landfill reveals varying extent of waste decomposition. The earth resistivity model of traverse 3 (Fig. 3a) reveals highly conductive (3$4.5 \mathrm{ohm}-\mathrm{m}$ ) zones at depth ranging from depth of 10$20 \mathrm{~m}$ in the southern end of the profile to greater than $40 \mathrm{~m}$ at the center of the profile, indicating the contamination of subsurface due to the incursion of contaminants into the shallow unconfined aquifer. High resistivity response zone exist at the northern end of the traverse and it is viewed as zone relatively free from leachate pollution. The model indicates very low resistivity response at $25-50 \mathrm{~m}$ on the surface of the landfill, signifying zone of advanced decomposition of waste where most of the leachates invade the underlying aquifer. Traverse 4 (Fig.3b) however, presents a different scenario. At the depth of $20 \mathrm{~m}$ and beyond exist a zone of high resistivity from the first electrode to $120 \mathrm{~m}$ from the beginning of the traverse, suggesting an uncontaminated water bearing sand, suitable for groundwater development. This zone is flanked by low resistivity region interpreted as leachate impregnated sand and indicating severe contamination of the aquiferous zone. Overlying the uncontaminated high resistivity zone is a horizontal layer of low resistivity zone $(<5 \mathrm{ohm}-\mathrm{m})$ at depth ranging from near surface $20 \mathrm{~m}$. The zone is interpreted as clayey material with low hydraulic conductivities, and is thus responsible for protecting the underlying aquiferous layer from leachates invasion from the surface. Therefore, the narrow, horizontal layer is not a contaminated aquifer, but clay protecting the underlying aquifer and do not reflect pollution.

\section{REFERENCES}

Ball, J M and Stove, J G (2002). Pollution plume migration: Coastal Park landfill. Proc. WasteCon- 
Geo-electrical investigation.....

2002. International water management biennial, Durban, South Africa.

Billman, H.G; (1992). Offshore Stratigraphy and Paleontology of the Dahomey Embayment,West African. NAPE Bulletin Vol. 7 (2) pp.121 - 130.

Bureau de Recherches Geologiques et Minieres (1979): Pre-drilling hydrogeological report area 18 and 19 sub-mitted to the Federal Department of Water Resources, Lagos, Nigera, pp.1-60

Elueze, A.A. and Nton,M.E., (2004). Organic geochemical appraisal of limestones and shales in part of eastern Dahomey basin, southwestern Nigeria. Journal of Mining and Geology, vol. 40, No. 1 pp 2940

Jones, H.A. and Hockey, R.D. (1964). The geology of part of Southwestern Nigeria. Geological Survey of Nigeria. Bull. 31,87p

Loke, M.H. and R D Barker, (1996). Practical techniques for 3D resistivity surveys and data inversion. Geo-physical Prospecting, 44, pp.499-523.
Longe, E O, Malomo, S Olorunniwo, M A (1987). Hydrogeology of Lagos Metropolis. Afr. J Earth Sci 6(2):163-174.

Omatsola, M. E. and Adegoke, O. S. (1981). Tectonic evolution and Cretaceous stratigraphy of the Dahomey basin. Journal of Mining Geology, 18 (1), p.130 -137.

Shaharin, I (1998). Investigation and Assessment of Municipal Landfill Sites in the Federal Territory of Kuala Lumpur (unpublished report),

Sasaki, Y (1992). Resolution of resistivity tomography inferred from numerical simulation. Geophys. Prospect. 40, pp.453-464.

Ugwu, S A and Nwosu, J I (2009). Effect of Waste Dumps on Groundwater in Choba using Geophysical Method. Journal of Applied Sciences Environ. Manage. March, 2009. Vol. 13(1) pp. 85 - 89. 